\title{
A large parasitengonid mite (Acari, Erythraeoidea) from the Early Cretaceous Crato Formation of Brazil
}

\author{
Jason A. Dunlop* \\ Museum für Naturkunde der Humboldt-Universität zu Berlin, Invalidenstraße 43, D-10115 Berlin, Germany
}

Received 30 November 2006, accepted 02 February 2007

Published 1 August 2007

With 4 figures

Key words: Arachnida, Parasitengona, Ceará State, Aptian, amber.

\begin{abstract}
A new large, fossil mite (Arachnida: Acari), Pararainbowia martilli n. gen. n. sp., is described from the Early Cretaceous (Aptian) Crato Formation from Ceará State, Brazil. It is assigned to the Cohort Parasitengona and the superfamily Erythraeoidea, some extant members of which can reach up to seven millimetres in body length. Given that doubts have been raised about the identity of putative Crato feather mite eggs, this new fossil represents the first unequivocal record of Acari from the Crato Formation, the first non-amber record of an erythraeoid mite and the oldest named example of this superfamily. Fossil erythraeoids from Mesozoic and Tertiary ambers are briefly reviewed - including a widely overlooked Late Cretaceous species - with comments on Mesozoic mites in general. Thirteen Baltic amber erythraeoids have been formally described, but much unstudied material from various amber sources remains.
\end{abstract}

Schlüsselworter: Arachnida, Parasitengona, Ceará State, Aptian, Bernstein.

\section{Zusammenfassung}

Ein neues großes Milbenfossil (Arachnida: Acari), Pararainbowia martilli n. gen. n. sp., wird aus der Crato Formation (Unterkreide, Aptium) des Ceará Gebietes in Brasilien beschrieben. Es wird der Kohorte Parasitengona und der Überfamilie Erythraeoidea zugeordnet; die modernen Vertreter erreichen eine Körperlänge bis zu sieben mm. Weil die Identität von Federmilbeneiern aus der Crato Formation in Frage gestellt wurde, ist dieser Neufund der erste klare Hinweis von Acari aus der Crato Formation. Es ist die erste erythraeoide Milbe, die nicht aus dem Bernstein stammt sowie das älteste genannte Beispiel dieser Überfamilie. Fossile erythraeoide Milben aus dem Bernstein des Mesozoikum und des Tertiärs werden kurz zusammengefasst - u. a. eine weitgehend übersehene Art aus der Oberkreide - mit allgemeinen Anmerkungen zu den mesozoischen Milben. Dreizehn erythraeoide Milbenarten sind aus dem baltischen Bernstein genannt und beschrieben worden, aber weiteres unbearbeitetes Material von verschiedenen Bernstein-Fundpunkten liegt noch vor.

\section{Introduction}

The Crato Formation of Ceará State, Brazil, is an important Early Cretaceous (ca. $115 \mathrm{Ma}$ ) deposit which has yielded numerous well-preserved fossils of vertebrates (fish, pterosaurs, and other tetrapods), invertebrates (especially insects, arachnids and crustaceans) and plants. In addition to the diverse insect fauna (e.g. Schlüter 2003), the Crato Forma- tion is one of only a few Mesozoic localities preserving considerable numbers of arachnids. The fauna described thus far includes spiders (Araneae), scorpions (Scorpiones), camel spiders (Solifugae), whip scorpions (Uropygi) and whip spiders (Amblypygi); see Dunlop et al. (in press) for a summary and further literature. Indirect evidence for mites (Acari) in the form of putative eggs on feathers has also been published (Martill \& Davis 1998), although

\footnotetext{
*E-mail: jason.dunlop@museum.hu-berlin.de
} 


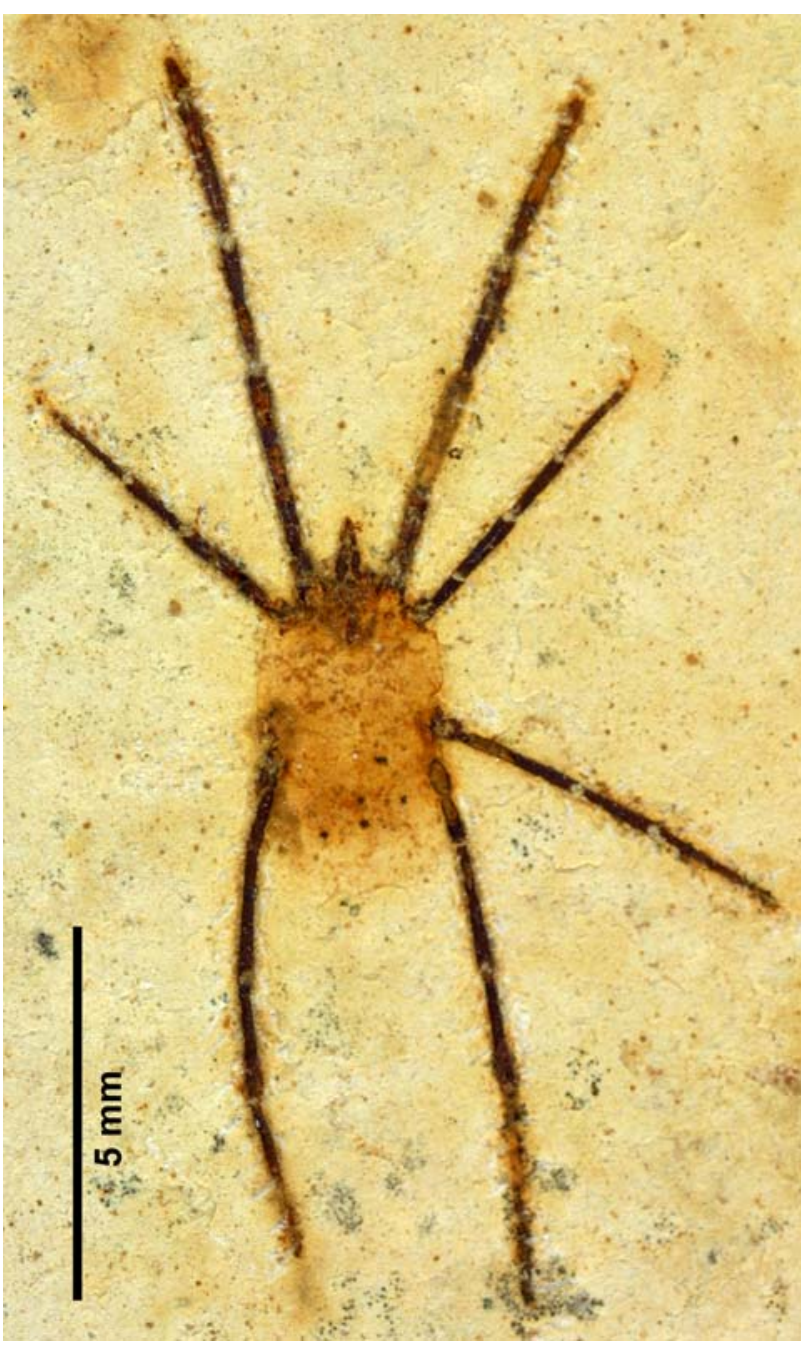

Fig. 1. Pararainbowia martilli n. gen. n. sp., a large erythraeoid mite (Acari: Parasitengona: ?Erythraeidae) from the Early Cretaceous (Aptian) of the Nova Olinda Member of the Crato Formation, Ceará State, Brazil.

this report was contradicted by Proctor (2003; see also below). Here, the first unequivocal fossil of a mite from the Crato Formation (Figs 1-3) is described. At nearly $5 \mathrm{~mm}$ in body length it is quite large, but can be assigned to the cohort Parasitengona and is clearly a member of the superfamily Erythraeoidea - some extant members of which are of a similar overall size and appearance (Fig. 4).

Parasitengonid mites are a specialized group which, following Welbourn (1991), comprise about 7000 extant species. They include both terrestrial and aquatic representatives and are typically characterized by a complex life-cycle in which at least one instar is ectoparasitic, either on other arthropods or vertebrates (e.g. Krantz 1978; Evans 1992). Adults are usually predatory. Familiar examples of parasitengonids include velvet mites, water mites (Hydracarina) and chiggers; the last being larval parasiten- gonids which can cause severe itching in humans. The parasitengonid superfamily Erythraeoidea - their name reflects the typical reddish colour of the body comprises two Recent and one fossil family, with some 200 extant species in 55 genera (Welbourn 1991). The most comprehensive account of their biology and systematics remains that of Southcott (1961).

Erythraeiod mites are free-living, terrestrial arachnids with a cosmopolitan distribution. They can be found on plants, in humus and on open ground, while some live arboreally or under bark. These mites are usually about $1-3 \mathrm{~mm}$ in body length, but can be larger. Among the most impressive living examples are those belonging to the Recent Australian genus Rainbowia Southcott, 1961 some of which can reach up to $7 \mathrm{~mm}$ in body length (Hirst 1928) as adults. Erythraeiod larvae tend to be parasites of arachnids or insects, but free-living and pollen-feeding larvae are also known. Larvae have been recorded attached to spiders, scorpions, harvestmen and even other mites. Among insects, they commonly parasitize groups such as grasshoppers and crickets (Orthoptera), cicadas, planthoppers and aphids (Homoptera), and booklice (Psocoptera); see e.g. Southcott (1961) for details. Both Orthoptera and Homoptera occur quite frequently within the Crato Formation insect assemblage.

\section{Material and methods}

The geological setting and dating of the Crato Formation has been described in detail elsewhere (e.g. Martill 1993). In brief, this is a finely laminated limestone outcropping in Ceará State, north-east Brazil which has been dated to Early Cretaceous (Aptian) on palynological data. The best material comes from the lowest 3-15 metres of the unit which is termed the Nova Olinda member. It is thought to represent a lake deposit with some floral and faunal elements (for example camel spiders among the arachnids) suggestive of an arid hinterland. The specimen described here belongs to the palaeontology collections of the Museum für Naturkunde, Berlin and is held under the repository number MB.A. 982 (for Museum Berlin, Arthropoda). A provisional label tentatively identifies it as an opilioacariform mite, but this referral is incorrect (see below). Limbs were carefully prepared from the matrix using a fine needle. Digital photographs were taken with a macro lens; drawings were made under a Leica MZ12.5 stereomicroscope using a camera lucida attachment.

\section{Morphological interpretation}

Like other arachnids from the Crato Formation, the new fossil (Figs 1-3) is preserved on a trimmed slab of pale yellow, fine-grained limestone. The specimen itself is darker than the matrix. Crato arthropods are typically preserved as reddish-brown geo-

Fig. 2. Camera lucida drawing of the specimen shown in Fig. 1. - Abbreviations: $\mathbf{b f}=$ basifemur, gs $=$ gnathosoma, is = idiosoma, $\mathbf{p p}=$ pedipalps, $\mathbf{g n}=$ genu $(=$ patella in non-mite terminologies $), \mathbf{t f}=$ telofemur, $\mathbf{t i}=$ tibia, $\mathbf{t r}=$ trochanter, ts $=$ tarsus. Legs numbered from 1 to 4 . 


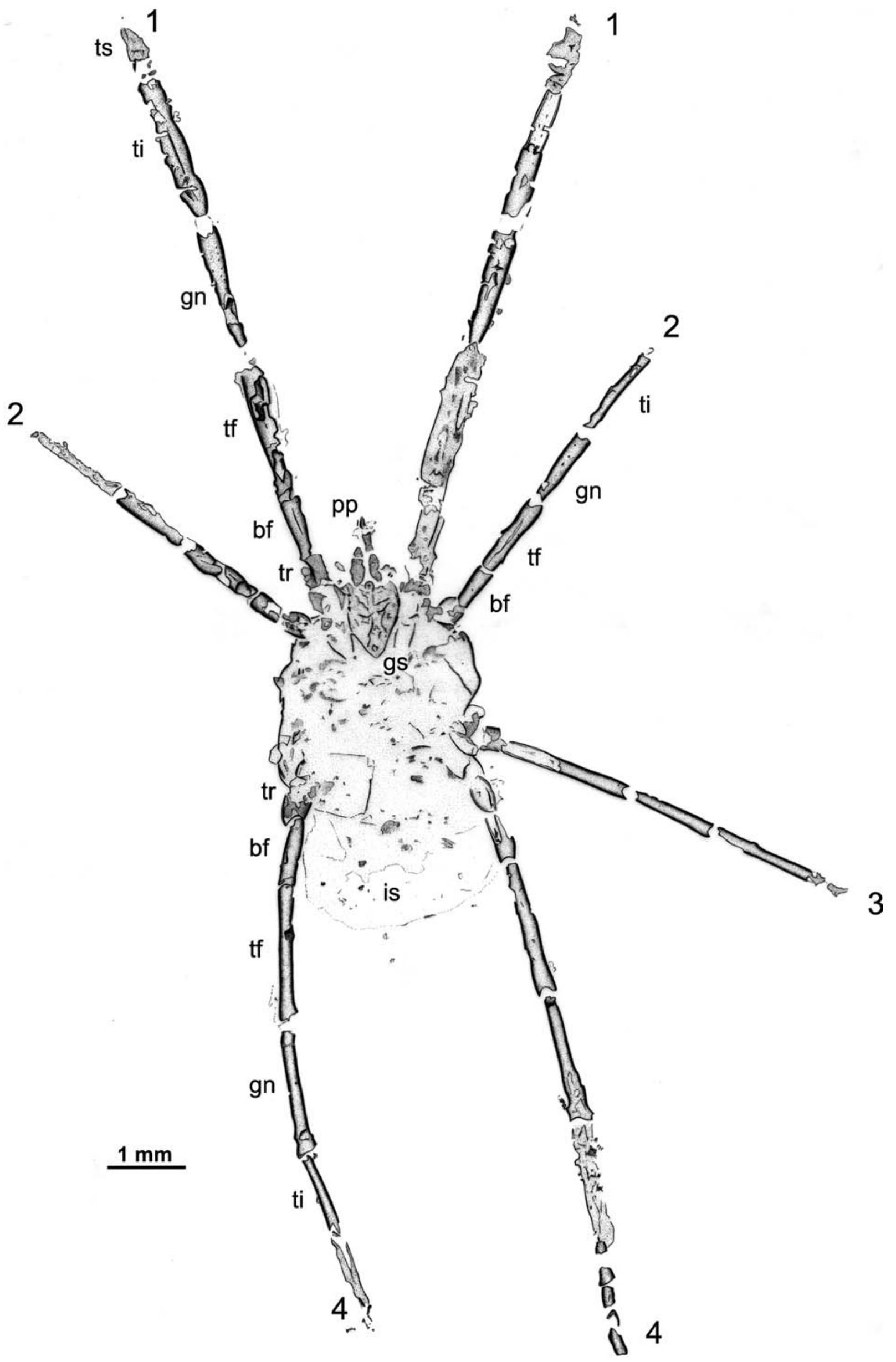




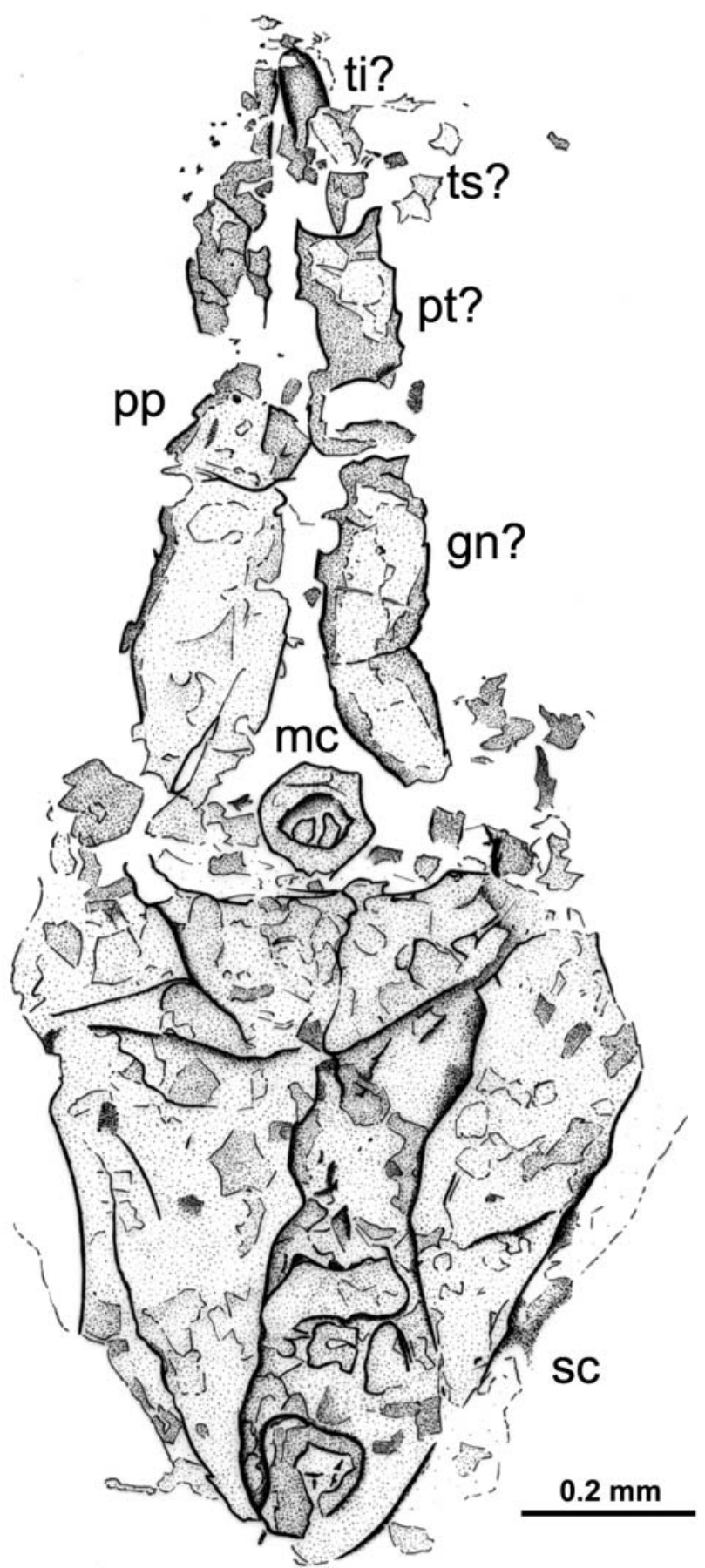

Fig. 3. Detail of the gnathosoma (mouthpart) region, ventral view. - Abbreviations: $\mathbf{m c}=$ mouth cone, a ring-like structure in cross section containing the bases of a pair of slender, styliform chelicerae, also preserved here in cross section, gn? = possible genu, $\mathbf{s c}=$ subcapitulum (i.e. fused pedipalpal coxae), ti? = possible tibia, ts? $=$ possible fragments of a rounded tarsus below the tibia. See text for details.

thetic pseudomorphs (e.g. Martill 1993) and the legs and mouthparts of this new fossil are dark brown; the rest of the body somewhat paler. The posterior margin of the body is effectively preserved only in outline. Typical for Crato arachnids, the legs of the new fossil are mostly three-dimensional, although some leg articles have become broken in places and are preserved either as hollow

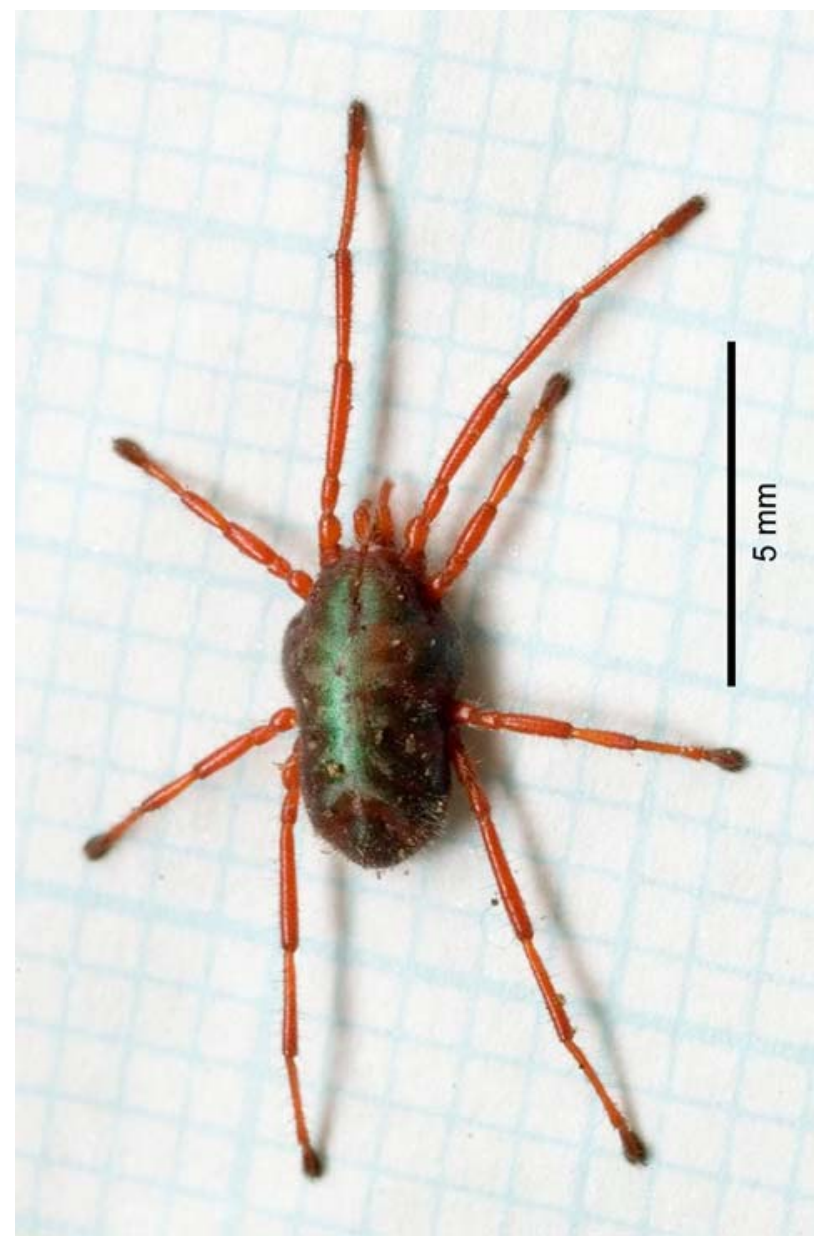

Fig. 4. A large modern erythraeid mite from Australia, tentatively identified as Rainbowia imperator (Hirst, 1928). This Recent example is of similar size (body length ca. $5 \mathrm{~mm}$, leg span ca. $15 \mathrm{~mm}$; background graph paper shows $\mathrm{mm}$ divisions) and overall appearance to the new Crato fossil described here. Photograph used with permission courtesy of David Nelson, Sydney $<$ http://davidavid.blogspot.com/>.

tubes or flatter impressions. The body itself generally lacks surface relief and bears irregular darker patches which are probably taphonomic in nature (?clots of minerals) rather than reflecting any biological structures. The legs are fairly complete, at least down to the tibia, although the third leg on the left side is missing.

This new fossil is evidently a mite (Acari) since it has a distinct gnathosoma region, i.e. the mouthparts and the fused coxae of the pedipalps together form a single functional unit. In acarological terminology, the rest of the body is referred to as the idiosoma. The most remarkable aspect of this fossil is its large size, approaching $5 \mathrm{~mm}$ in body length. Most mites are considerably smaller and as fossils have been macerated from sediments or (more commonly) represent inclusions in amber. The new fossil is preserved in ventral view, as revealed by the gnathosoma, which is usually on the underside of the body, and the strongly indented distal margins of many of the leg articles. Nomenclature for these articles essentially follow the scheme in 
Evans (1992) with, from proximal to distal, coxa, trochanter basifemur, telofemur, genu (or patella), tibia and tarsus. Thus unlike most other arachnid orders, these mites have a divided femur, but do not have a tarsus divided into a meta- or basitarsus. If the fossil's assignment to ?Erythraeidae is correct (see below) then one would expect one or two pairs of eyes and a band-like median structure called the crista metopica between them. Due to its ventral preservation, eyes could not be resolved in this new material and the crista is also equivocal.

Some details of the gnathosoma are, however, preserved (Fig. 3). The subcapitulum, formed from the fused coxae of the pedipalps, has an inverted subtriangular shape. Distinctly preserved in front of the subcapitulum is a circular structure containing two further ring-like features. Compared to modern erythraeoid mites, the paired structures are almost certainly cross sections through the bases of the slender, paired chelicerae, which are described in Recent examples of such mites as being styliform in nature (e.g. Southcott 1961). The chelicerae themselves are further described as lying within, and protruding distally through the lips of, a so-called mouth cone or rostrum (Southcott 1961). It is thus conceivable that the distinct ring surrounding the chelicerae in the fossil (Fig. 3: mc) is a cross section through the proximal region of such a mouth cone.

Flanking the putative mouth cone are a pair of small, pediform pedipalps. Precise article boundaries are difficult to establish in the fossil, but a tentative homology scheme drawing on extant erythraedids is shown in Fig. 3. In living examples of this group the distal end of the palp is rather complex (e.g. Southcott 1946; 1961). The tarsus is very small and almost hemispherical in shape - hence the interpretation of the disal-most element in the fossil as the tibia - and tucks underneath the tibia. The tibia itself bears a movable claw in extant forms, which on a first impression could be mistaken for the tarsus. This expected tibial claw cannot be resolved with confidence in the fossil, but it is notable that there are sclerotised elements preserved to the right of the distal end of the right pedipalp in the fossil which define a vaguely circular region (Fig. 3: ts?). Bearing in mind this is a ventral view, these might represent the remains of the original rounded tarsus below the tibia, but more complete material is required to confirm this.

\section{Systematic palaeontology}

Cohort Parasitengona Oudemans, 1909

Superfamily Erythraeoidea Grandjean, 1947

Remarks. Only a few living groups of mites approach, or reach, the size of this fossil. Mites (Acari) are generally divided into two orders: Anactinotrichida (or Parasitiformes) and Actinotrichida (or Acariformes). Among the anactinotrichids, Opilioacariformes, Holothyrida and Ixodoida (ticks) can be quite large. The new Crato fossil lacks the distinctive habitus and robust, piercing mouthparts of both hard and soft ticks and its long, slender legs are also quite unlike those of both ticks and holothyrids; see e.g. illustrations in Evans (1992). The long legs crudely resemble those of opilioacariform mites (hence its provisional identification as such), the only fossil of which was recently described from Baltic amber by Dunlop et al. (2004). Extant opilioacariforms normally only reach about $2-3 \mathrm{~mm}$ in length (Evans 1992). Compared to illustrations in van der Hammen (1966), the habitus of the Crato fossil is inconsistent with Opilioacariformes. In particular the limb bases should be congregated towards the front of the animal and the pedipalps should be somewhat larger and more robust.

Among actinotrichid mites, some members of the Parasitengona achieve large size, including certain velvet mites (Trombidiidae) and Erythraeoidea. The delicate legs in this fossil argue strongly against it being a giant velvet mite, which are usually much more stocky in appearance and have a dense coating of velvety hair. Other Crato arachnids often preserve setae in extraordinary detail and if the new fossil had thick hairs in life, some trace of this ought to be present, at least associated with the well preserved legs. In general, the habitus and longer legs of the new fossil is much more characteristic for an erythraeid (compare especially Figs 1-2 and 4) than for a trombidiform mite.

\section{Family ?Erythraeidae Robineau-Desvoidy, 1828}

Remarks. The superfamily Erythraeoidea comprises two extant families: Erythraeidae and Smarididae, plus the monotypic fossil family Protoerythraeidae (see also below). The latter was defined on its unusual setation by Vercammen-Grandjean (1973a); a character which cannot be tested in our new fossil which preserves only fragments of leg setae. The large size and somewhat ellipsoid body of the new fossil generally favours an erythraeid (see e.g. Southcott 1961) since smaridids tend to be smaller with a prominent nasus projecting forwards and bearing the mouthparts on a distinct collar or sleeve (the armilla); a character which cannot be seen in this fossil. Resolving unequivocally between the families is difficult based on the characters preserved, which do not include obvious apomorphies of the three known taxa, but the Crato fossil is tentatively assigned here to Erythraeidae.

\section{Pararainbowia n. gen.}

Derivation of name. From its similarity to the extant erythraeid mite genus Rainbowia, characterised by a similar large body size.

Type and only species. Pararainbowia martilli sp. nov. 
Diagnosis. Large fossil erythraeoid mite in which the first pair of legs is slightly more robust than the other walking appendages.

Remarks. Most of the characters available for the taxonomy of extant species (see Southcott 1946) such as those relating to setae and fine structures of the pedipalps are not preserved in the fossil which thus has to be largely distinguished by its age. This is not entirely satisfactory, but the somewhat more robust first legs do offer a possible character by which the fossil differs from extant forms where this is not so obvious.

\section{Pararainbowia martilli n. sp.}

Figs $1-3$

Derivation of name. For Dr Dave Martill (Portsmouth, UK), in recognition of his extensive work on the Crato Formation, and for making numerous important arachnid specimens available to me over the years.

Holotype and only specimen. An almost complete specimen in ventral view; MB.A. 982.

Type horizon and locality. From the Nova Olinda member of the Crato Formation, Ceará State, north-eastern Brazil; Early Cretaceous (Aptian).

Diagnosis. As for the genus.

Description. Total length $4.6 \mathrm{~mm}$, maximum width $2.7 \mathrm{~mm}$. Gnathosoma oval to diamond shaped, length $1.0 \mathrm{~mm}$, maximum width $0.7 \mathrm{~mm}$, slightly offset against the idiosoma. Bases of chelicerae preserved in cross section as adjacent rings, probably indicating styliform structures in life; both set within a larger ring of cuticle, probably the mouth cone. Pedipalps $0.9 \mathrm{~mm}$ long, pediform, bluntly rounded at the tip (tibia?) with possible fragments of a tarsus adjacent to the putative tibia. Idiosoma essentially oval, but with a distinct narrowing, to $2.4 \mathrm{~mm}$, in the middle, at about the level of the third pair of legs. Details poor, particularly towards the posterior end of the idiosoma. Legs relatively complete, elongate and slender, but full length not preserved. Leg formula (longest to shortest) probably 4, 1, 3, 2; leg 1 noticeably more robust than the other legs; maximum leg span at least $19 \mathrm{~mm}$ Measurable articles and maximum preserved lengths in $\mathrm{mm}$ are as follows. Leg 1: trochanter, 0.4 ; basifemur, 0.8 ; telofemur, 1.8; patella 1.9, tibia 2.2; tarsus ca. 0.7 ; total length ca. 7.8. Leg 2: trochanter, 0.4; basifemur, 0.6; telofemur, 1.1; patella 1.1, tibia 1.3; tarsus unknown; total preserved length 4.5. Leg 3: trochanter, 0.5; basifemur, 0.8 ; telofemur, 1.0 ; patella 1.2 , tibia 1.6 ; tarsus unknown; total preserved length 5.1. Leg 4: trochanter, 0.5; basifemur, 0.9; telofemur, 1.9; patella, 1.7; tibia, 2.2; tarsus, ca. 1 ; total length ca. 8.2.

\section{Other fossil Erythraeoidea}

In addition to the new Crato Formation (Aptian) specimen described here, fossil erythraeoid mites have been reported from the following Mesozoic ambers: Lebanese (Aptian), Burmese (probably Albian), New Jersey (Turonian), Siberian (probably Santonian) and Canadian (probably Campanian). The larval Canadian specimen from Cedar Lake, Manitoba was first noted by Ewing (1937); see also McAlpine \& Martin (1969) and Žerichin (1978). It was formally described as Proterythraeus southcotti Vercammen-Grandjean, 1973a. This name was overlooked in later summaries of the mite fossil record (e.g. Keilbach 1982; Bernini 1986; Selden 1992), but was picked up in the comprehensive listings of amber inclusions by Spahr (1993). Proterythraeus Vercammen-Grandjean 1973a was placed in a new, monotypic family, Proterythraeidae, defined by an unusual pattern of leg setation. The genus and family were listed (without citations!) by Vercammen-Grandjean 1973b and the fossil family name was mentioned by Krantz (1978, p. 277). The Mesozoic erythraeoids from Lebanese (Azar 2000), New Jersey (Grimaldi et al. 2000), Siberian (cited indirectly by Spahr 1993) and Burmese (Grimaldi et al. 2002) amber have not been formally described. Confirmation of these provisional identifications would be welcome.

There is also an assemblage of fossil Erythraeidae from Palaeogene Baltic amber, originally described by Koch \& Berendt (1854) and Menge (1854); the latter as footnotes to Koch \& Berendt's paper. Spahr (1993) listed thirteen Baltic amber species. These were originally referred to the extant genera Rhyncholophus Dugès, 1834 and Erythraeus Latrielle, 1806. One, Arythaena troguloides Menge, 1854, was assigned to an extinct genus. The apparent loss of Menge's types from Gdansk coupled with a lack of illustrations makes assessing the validity of this fossil genus - and the placement of his other seven species - difficult. Note that Rhyncholophus at that time represented a 'grab-bag' of species, now recognised as members of different families such that it may no longer contain any genuine erythraeids. Indeed Koch \& Berendt's five Rhyncholophus species were reassigned (sometimes tentatively) by Oudemans (1937) and Vitzthum (1942) either to Erythraeus, or to other extant genera, namely Leptus Latrielle, 1796 and Balaustium v. Heyden, 1826. Both authors almost certainly relied on Koch \& Berendt's original drawings which tend to be idealised reconstructions rather than wholly accurate camera lucidas (pers. obs.). Southcott (1961) noted that Oudemans and Vitzthum offered no useful characters other than body size in support of their species placements. A brief survey of the postVitzthum literature (e.g. Petrunkevitch 1955; Dubinin 1962; Keilbach 1982; Selden 1992; Spahr 1993) revealed numerous published inconsistencies with respect to the total number of unequivocal Baltic amber erythraeid species - e.g. Keilbach regarded some without comment as nomina nuda - and their correct generic assignment. 
Undescribed Smarididae were noted from Baltic amber by Kulicka (1990) and both this family and Erythraeidae sp. were listed by e.g. Kupryjanowicz (2001) from the Giecewicz Baltic amber collection in Warsaw. A larval Erythraeidae parasitizing a moth in the probably slightly younger Dominican amber was mentioned by Poinar et al. (1991). Finally, there is a report of the family from the Pleistocene Copal of Mizunami, Gifu Prefecture, Japan (Aoki 1974; Hiura \& Miyatake 1974).

\section{Other Mesozoic mites}

Given their small size and usually poorly sclerotised bodies it is hardly surprising that Mesozoic mites are fairly uncommon. There are no Triassic records whatsoever. Oribatid (moss or box mites) are an important component of many soil faunas and thanks to their often heavily armoured bodies, they tend to be rather more robust than other mite groups. From the Early Jurassic (Lower Sinemurian) comes a representative of an extant, secondarily aquatic, oribatid genus (Sivhed \& Wallwork 1978). There is also a reasonably diverse spectrum of five oribatid species from Upper Jurassic sediments from the Burea River bank in Siberia (Krivolutsky \& Krasilov 1977). These have been assigned to the 'higher' families (Cymbaeremeidae, Astegistidae and Achipteridae) and the 'lower' oribatid superfamily Nothroidea; see also Krivolutsky \& Druk (1986) or Bernini (1986) for reviews.

All Cretaceous mites described previously are inclusions in amber and Grimaldi et al. (2002) suggested that all late Cretaceous ambers will probably yield mites eventually. Oribatids from the Tamyr Peninsula (Siberian) amber have been formally described as members of the family Camisiidae (Bulanova-Zachvatkina 1974; Krivolutsky \& Ryabinin 1976). Oribatids from Canadian amber have been provisionally assigned to the families Oribatulidae and Gymnodamaeidae (Ewing 1937). From New Jersey amber there is a record of Oribatida (Lindquist in Grimaldi et al. 2000). Oribatid mite detritivory in the (non-amber) Cretaceous of the Antarctic has been inferred by Kellogg \& Taylor (2004). Other Cretaceous mites in amber belong to various trombidiform groups. From Lebanese, Burmese and New Jersey amber come the erythraeoids (see above), as well as records of Anystidae, Cheyletidae, Bdellidae and Eupodidae; all undescribed at the genus and species level. Finally, there is an undescribed record of juvenile hard ticks (Ixodidae) in Burmese amber (Grimaldi et al. 2002) and a bird - or perhaps feathered dinosaur - soft tick (Argasidae) in New Jersey amber which was formally described by Klompen \& Grimaldi (2001). See also Spahr (1993) for further citations about amber mites in the literature.

\section{Crato feather mites?}

Martill \& Davis (1998) reported tiny, spherical structures preserved on feathers in the Crato Formation. These egg-like objects have a diameter of ca. $70 \mu \mathrm{m}$ and a circular aperture of about $35-40 \mu \mathrm{m}$. They were interpreted as evidence of ecotoparasitism. Bird lice were excluded as potential producers due to the small size of the spheres. Instead, these authors suggested that the feathers hosted mites, several groups of which are known from modern bird families and which lay their eggs attached directly to the feathers. Martill \& Davis were unable to assign the eggs to any particular taxon. In her review of feather mite biology, Proctor (2003) disputed this hypothesis, pointing out that eggs of Recent feather mites (Acari: Astigmata) are typically larger $(150-400 \mu \mathrm{m})$, sausage-shaped and have a longitudinal seam rather than an aperture. She suggested ostracods as an alternative source, a group known to lay spherical eggs on aquatic detritus, such as a feather washed into a lake.

\section{Acknowledgements}

I thank Christian Neumann (Berlin) for access to material in his care, Michael Ohl (Berlin) for assistance with photography, Cal Welbourn (Gainesville) for helpful comments, David Nelson (Sydney) for permission to use a photograph of a Recent species, and Paul Selden and an anonymous reviewer for their valuable suggestions.

\section{References}

Aoki, J. 1974. Mizunami amber and fossil insects. 3. Arachnida: Acarina. - Bulletin of the Mizunami Fossil Museum 1: 397-400. [English summary]

Azar, D. 2000. Les Ambres Mésozoïques du Liban. Ph.D dissertation. Orsay (University of Paris).

Bernini, F. 1986. Current ideas on the phylogeny and the adaptive radiations of Acarida. - Bollettino di Zoologia 53: 279-313.

Bulanova-Zachvatkina, E. M. 1974. New genera of oribatid mites from the Upper Cretaceous of Tajmyr. - Paleontological Journal 1974 (2): 141-144. [In Russian]

Dubinin, V. B. 1962. Class Acaromorpha: mites or gnathosomic chelicerate arthropods. 681-722. - In Rodendorf, B. B. (ed.) Fundamentals of Paleontology. Volume 9 [1991 Translation]. Smithsonian Libraries and National Science Foundation, Washington DC.

Dugès, A. 1834. Recherches sur l'ordre des Acariens et la famille des Trombidés en particular. - Annales des Sciences Naturelles, Zoologie (Series 2) 1: 5-46.

Dunlop, J. A.; Menon, F. \& Selden, P. A. in press. Arachnida. - In Martill, D. M. (ed.) The Crato Fossil Beds of Brazil: Window into an Ancient World. Cambridge University Press, Cambridge.

Dunlop, J. A.; Wunderlich, J. \& Poinar jr., G. O. 2004. The first fossil opilioacariform mite (Acari: Opilioacariformes) and the first Baltic amber camel spider (Solifugae). Transactions of the Royal Society of Edinburgh: Earth Sciences 94: 261-273.

Evans, G. O. 1992. Principles of Acarology. xviii +563 pp., C.A.B. International, Wallingford. 
Ewing, H. E. 1937. Insects and arachnids from Canadian amber: Arachnida, Order Acarina. - University of Toronto Studies in Geology 40: 56-62.

Grandjean, F. 1947. Études sur les Smarisidae et quelques autres Érythroïdes (Acariens). - Archives de Zoologie Expérimentale et Générale 85: 1-126.

Grimaldi, D.; Shedrinsky, A. \& Wampler, T. P. 2000. A remarkable deposit of fossiliferous amber from the Upper Cretaceous (Turonian) of New Jersey. 1-76. - In Grimaldi, D. (ed.) Studies on Fossils in Amber, With Particular Reference to the Cretaceous of New Jersey. Backhuys Publishers, Leiden.

Grimaldi, D.; Engel, M. S. \& Nascimbene, P. 2002. Fossiliferous Cretaceous amber from Burma (Myanmar): Its rediscovery, biotic diversity and paleontological significance. American Museum Novitates 3361: 1-71.

Hammen, L. van der 1966. Studies on Opilioacarida (Arachnida). I. Description of Opilioacarus texanus (Chamberlin \& Mulaik) and revised classification of the genera. Zoologische Verhandelingen 86: 1-80.

Heyden, C. H. G von 1826. Versuch einer systematischen Eintheilung der Acariden. - Isis von Oken 18: 609-613.

Hirst, S. 1928. On some new Australian mites of the families Trombidiidae and Erythraeidae. - Annals and Magazine of Natural History, Tenth Series 1: 563-571.

Hiura, I. \& Miyatake, Y. 1974. Mizunami amber and fossil insects. 1. On the fossil Arthropoda in Mizunami amber from Gifu Prefecture (Pleistocene). - Bulletin of the Mizunami Fossil Museum 1: 385-392. [English summary]

Keilbach, R. 1982. Bibliographie und Liste der Arten tierischer Einschlüsse in fossilen Harzen sowie ihrer Aufbewahrungsorte. Teil 1. - Deutsche Entomologische Zeitschrift, N.F. 29: 129-286.

Kellogg, D. W. \& Taylor, E. L. 2004. Evidence of oribatid mite detritivory in Antarctica during the late Paleozoic and Mesozoic. - Journal of Paleontology 78: 1146-1153.

Klompen, J. S. H. \& Grimaldi, D. 2001. First Mesozoic record of a parasitiform mite, a larval argasid tick in Cretaceous amber (Acari: Ixodida: Argasidae). - Annals of the Entomological Society of America 94: 10-15.

Koch, C. L. \& Berendt, G. C. 1854. Die im Bernstein befindlichen Crustaceen, Myriapoden, Arachniden und Apteren der Vorwelt. 124 pp., Berlin (Edwin Groening), Berlin.

Krantz, G. W. 1978. A Manual of Acarology, Second Edition. 509 pp., Oregon State University Book Stores Inc., Corvallis.

Krivolutsky, D. A. \& Druck, A. Y. 1986. Fossil oribatid mites. Annual Review of Entomology 31: 533-545.

Krivolutsky, D. A. \& Krasilov, B. A. 1977. Oribatid mites from Upper Jura deposits of USSR. 16-24. - In Skarlato, O. A. \& Balashov, Y. S. (eds) Morphology and Diagnostics of Mites. Zoological Institute, Leningrad. [In Russian]

Krivolutsky, D. A. \& Ryabinin, N. A. 1976. Oribatid mites in Siberian and Far East amber. - Reports of the Academy of Science of the USSR 230: 945-948.

Kulicka, R. 1990. The list of animal inclusions in Baltic amber from collection of the Museum of Earth in Warsaw. Prace Muzeum Ziemi 41: 144-146.

Kurpryjanowicz, J. 2001. Arthropods in Baltic amber and their photographic record. 19-72. - In Kosmowska-Ceranowicz, B. (ed.) The Amber Treasure Trove. Part 1. 97 pp., Museum of the Earth Documentary Studies, No. 18, Warsaw.

Latreille, P. A. 1796. Précis des caractères génériques des Insectes, disposés dans un ordre naturel. 179 pp., Prevot, Paris.

- 1806. Genera crustaceorum et insectorum, secundum ordinem naturalem in familias disposita, iconibus exemplisque plurimis explicata. Vol. 1. 303 pp., Amand Koenig, Paris.

Martill, D. M. 1993. Fossils of the Santana and Crato Formations, Brazil. - The Palaeontological Association Field Guides to Fossils 5: 1-159.
Martill, D. M. \& Davis, P. G. 1998. Did dinosaurs come up to scratch? - Nature 396: 528-529.

McAlpine, J. F. \& Martin, J. E. H. 1969. Canadian amber - a palaeontological treasure chest. - The Canadian Entomologist 101: 819-838.

Menge, A. 1854. Footnotes. - In Koch, C. L. \& Berendt, G. C. Die im Bernstein befindlichen Crustaceen, Myriapoden, Arachniden und Apteren der Vorwelt. 124 pp., Edwin Groening, Berlin.

Oudemans, A. C. 1909. Über die bis jetzt genauer bekannten Thrombidium-larven und über eine neue Klassifikation der Prostigmata. - Tijdschrift voor Entomologie 52: 1961.

- 1937. Kritisch Historisch Overzicht der Acarologie, Vol. III, Band C-G. 2735 pp., E. J. Brill, Leiden.

Petrunkevitch, A. I. 1955. Arachnida. 42-162. - In Moore, R. C. (ed.) Treatise on Invertebrate Paleontology, Part P, Arthropoda 2. 181 pp., Geological Society of America and University of Kansas Press, Lawrence, Kansas.

Poinar jr., G. O.; Treat, A. E. \& Southcott, R. V. 1991. Mite parasitism of moths: Examples of palaeosymbiosis in Dominican amber. - Experientia 47: 210-212.

Proctor, H. C. 2003. Feather mites (Acari: Astigmata): ecology, behavior, and evolution. - Annual Review of Entomology 48: 185-209.

Robineau-Desvoidy, J. B. 1828. Recherches sur l'organisation vertébrale des Crustacés, Arachnides et Insectes. - 228 pp., Comprè Jeune, Paris.

Schlüter, T. 2003. Fossil insects in Gondwana - localities and palaeodiversity trends. - Acta zoologica Cracoviensia, 46 (suppl.-Fossil Insects): 345-371.

Selden, P. A. 1992. Arthropoda (Aglaspidida, Pycnogonida and Chelicerata). 297-320. - In Benton, M. J. (ed.) The Fossil Record 2. Chapman and Hall, London.

Sivhed, U. \& Wallwork, J. A. 1978. An early Jurassic oribatid mite from southern Sweden. - Geologiska Föreningens I Stockholm Förhandlingar 100: 65-70.

Southcott, R. V. 1946. Studies on Australian Erythraeidae (Acarina). - Proceedings of the Linnean Society of New South Wales 71: 6-48.

- 1961. Studies on the systematics and biology of the Erythraeoidea (Acarina), with a critical revision of the genera and subfamilies. - Australian Journal of Zoology 9: $367-610$.

Spahr, U. 1993. Ergänzungen und Berichtigungen zu R. Keilbachs Bibliographie und Liste der Bernsteinfossilien Verschiedene Tiergruppen, ausgenommen Insecta und Araneae. - Stuttgarter Beiträge zur Naturkunde, Serie B (Geologie und Paläontologie) 194: 1-77.

Vercammen-Grandjean, P. H. 1973a. Study of the "Erythraeidae, R.O.M. No. 8" of Ewing, 1937. 329-335. - In Daniel, M. \& Rosický, B. (eds) Proceedings of the $3^{\text {rd }}$ International Congress of Acarology held in Prague (Czechoslovakia), August 31-September 6, 1971. 837 pp., Academia, Prague.

Vercammen-Grandjean, P. H. 1973b. Sur les status de la famille des Trombidiidae Leach, 1815 (Acarina: Prostigmata). Acarologia 15: 102-114.

Vitzthum, H. Graf 1940-43. Acarina. - In Dr. H. G. Bronns (ed.) Klassen und Ordnungen des Tierreichs, Band 5, Abteilung IV, Buch 5. 1911 pp., Akademische Verlagsgesellschaft, Leipzig.

Welbourn, W. C. 1991. Phylogenetic studies of the terrestrial Parasitengona. 163-170. - In Dusbábek, F. \& Bukva, V. (eds) Modern Acarology, Volume 2. ix +779 pp, Academia, Prague \& SPB Academic Publishing, The Hague.

Žerichin, V. V. 1978. Razvitie i Smena melovych i kajinozojskich faunističeskich Kompleksov. (Trachejnye i Chelicerovye). - Trudy paleontologičeskogo Instituta 165: 1198. 